\title{
Androgen receptor (AR) in cardiovascular diseases
}

\section{Chiung-Kuei Huang', Soo Ok Lee', Eugene Chang1,3, Haiyan Pang' and Chawnshang Chang ${ }^{1,2}$}

${ }^{1}$ George Whipple Lab for Cancer Research. Departments of Pathology, Urology, and The Wilmot Cancer Center, University of Rochester Medical Center, Rochester, NY, USA

2 Sex Hormone Research Center, China Medical University/Hospital, Taichung, Taiwan

${ }^{3}$ Department of Medicine, Case Cardiovascular Institute Research Institute, Case Western Reserve University, Cleveland, OH, USA
Correspondence should be addressed to C Chang

Email

chang@urmc.rochester.edu

\begin{abstract}
Cardiovascular diseases (CVDs) are still the highest leading cause of death worldwide. Several risk factors have been linked to CVDs, including smoking, diabetes, hyperlipidemia, and gender among others. Sex hormones, especially the androgen and its receptor, androgen receptor (AR), have been linked to many diseases with a clear gender difference. Here, we summarize the effects of androgen/AR on CVDs, including hypertension, stroke, atherosclerosis, abdominal aortic aneurysm (AAA), myocardial hypertrophy, and heart failure, as well as the metabolic syndrome/diabetes and their impacts on CVDs. Androgen/AR signaling exacerbates hypertension, and anti-androgens may suppress hypertension. Androgen/AR signaling plays dual roles in strokes, depending on different kinds of factors; however, generally males have a higher incidence of strokes than females. Androgen and AR differentially modulate atherosclerosis. Androgen deficiency causes elevated lipid accumulation to enhance atherosclerosis; however, targeting AR in selective cells without altering serum androgen levels would suppress atherosclerosis progression. Androgen/AR signaling is crucial in AAA development and progression, and targeting androgen/AR profoundly restricts AAA progression. Men have increased cardiac hypertrophy compared with age-matched women that may be due to androgens. Finally, androgen/AR plays important roles in contributing to obesity and insulin/leptin resistance to increase the metabolic syndrome.
\end{abstract}

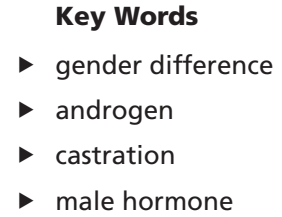

Journal of Endocrinology (2016) 229, R1-R16

\section{Introduction}

Globally, cardiovascular diseases (CVDs) are still the highest cause of death worldwide in developed countries and developing countries (Gaziano et al. 2010). Several risk factors, including smoking, diabetes, and hyperlipidemia, play critical roles in the occurrence of CVDs (Zimmerman 2012). The gender difference is another key risk factor affecting CVDs (Banos et al. 2011).

Among the factors associated with the gender difference, sex hormones, including estrogens and androgens, are two key factors that have been studied extensively (Simon 2001). Postmenopausal women have decreased estrogen levels, and the decline of female hormone has been linked to elevated risk of CVDs in women for years; yet, some clinical trials concluded that estrogen treatment failed to improve the risk of CVDs in menopausal women (Hulley et al. 1998, Rossouw et al. 2002, Toh et al. 2010).

Published by Bioscientifica Ltd 
In contrast to estrogens, the effects of androgens on CVDs have rarely been studied, although early reports documented well that patients with CVDs have low serum testosterone (Dunajska et al. 2004, Turhan et al. 2007, Hu et al. 2011). As gender differences have been shown in CVDs with a higher incidence in males, androgens might promote CVDs. However, a protective role of androgens for CVDs was also reported (Malkin et al. 2003). A recent prospective study revealed that men whose total testosterone levels were in the lowest quartile were $40 \%$ more likely to die from CVDs than those with higher levels (Laughlin et al. 2008). Other studies showed that androgen deprivation therapy (ADT) led to increased risk of higher CVDs (Hu et al. 2012, Razzak 2012), and accordingly, the androgen replacement therapy (ART) has been applied and patients indeed showed improvement in heart functions (Vigna \& Bergami 2005, Kang et al. 2012).

Due to this dilemma, recent studies were shifted to the effects of the androgen receptor (AR) rather than androgens on CVDs, as androgens might exert their effects through both AR and non-AR (non-genomic) actions (Heinlein \& Chang 2002, Kang et al. 2004), as well as the fact that AR could be activated via both androgenand non-androgen-mediated manners (Sugita et al. 2004). Importantly, the potential therapy of targeting AR in selective cells may have fewer side effects than targeting androgens using ADT.

Before the generation of $A r$-knockout (ARKO) mice (Yeh et al. 2002), most androgen/AR studies in CVDs were performed with castrated mice or rats, which resulted in significant reduction of serum androgen levels (Malyusz et al. 1985, Alexandersen et al. 1999, Li et al. 2004, Henriques et al. 2008). However, the studies on castrated animals failed to directly address the AR effects on CVDs. Using the Cre-LoxP strategy, several mouse models with knockout of $A r$ in the whole body or in specific cell types, including general ARKO (GARKO, knockout in whole body), neuronal cell ARKO (NARKO) (Yu et al. 2013), macrophage lineage cell ARKO (MARKO), endothelial cell ARKO (EARKO), and smooth muscle cell ARKO (SARKO) were generated to study the impacts of cell-specific AR on CVDs (Yeh et al. 2002, Huang et al. 2014).

This review summarizes recent discoveries related to the effects of androgen/AR on CVDs, starting with hypertension then moving to the other CVDs, including stroke, myocardial hypertrophy, abdominal aortic aneurysm (AAA), and atherosclerosis, as well as metabolism.

\section{Androgen/AR roles in hypertension}

Hypertension or increased arterial blood pressure is one of the most prevalent CVDs affecting $25 \%$ of the adult population in the USA (Burt et al. 1995). Patients with long-term hypertension could also have increased risks of having other CVDs, including stroke, AAA, atherosclerosis, myocardial infarction, and congestive heart failure (Kannel 2000).

There are several risk factors linked to hypertension, such as age, obesity, alcohol abuse, and gender difference (Reckelhoff 2001). In human studies, men generally have higher blood pressure than women (Khoury et al. 1992, Burt et al. 1995, Wiinberg et al. 1995, Egan et al. 2010). However, the difference is gradually lost after women have passed menopause and men have declining androgen levels at ages around 70-79 years old (Burt et al. 1995). These observations suggest that sex hormones are involved in the progression of hypertension.

To clarify whether gender modulates hypertension, early studies have investigated the impact of gender on hypertension and demonstrated that male rats have higher blood pressure than females in several hypertensive rat studies (Iams et al. 1979, Ganten et al. 1989, Chen \& Meng 1991), as well as the chemical-induced Dahl salt-sensitive (DS) rats (Rowland \& Fregly 1992), deoxycorticosterone-salthypertensive rats (Ouchi et al. 1987), and the genetic mutation New Zealand hypertensive rats (Ashton \& Balment 1991). In addition, several studies also showed similar observations in mouse models. Angiotensin II infusion significantly increased blood pressure in males, but to a lesser extent in females (Xue et al. 2005). The COX II-deficient mouse model also had higher blood pressures in males than females (Yang et al. 2005). From the human epidemiological and animal studies, it is clear that sex hormones modulate blood pressure.

Estrogens were originally proposed to have a protective role in blood pressure. Thus, several clinical trials have been proposed aiming to determine whether estrogens could inhibit blood pressure in postmenopausal women. However, the clinical studies failed to show convincing improvement after treating postmenopausal women with estrogen supplements (PEPI Trial Writing Group 1995, Rossouw et al. 2002, Anderson et al. 2004).

Interestingly, androgens gradually emerged as new candidates to account for the gender differences in CVDs. In older males, having decreased androgens and increased blood pressure, androgen supplement might reduce the blood pressure. However, the androgen treatment was found to exacerbate hypertension and increase the risk of

Published by Bioscientifica Ltd. 
CVDs (Tangredi \& Buxton 2001, Reckelhoff et al. 2005). In animal studies, Reckelhoff et al. made comparisons among male rats with various conditions, including noncastrated, castrated, anti-androgen flutamide-treated, and female rats. They found that the surgical and chemical castrations in these males reduced blood pressure levels down to the similar levels as observed in females (Reckelhoff et al. 1999). Similar results were reported in other castrated animal models (Malyusz \& Ehrens 1983, Malyusz et al. 1985, Woods et al. 2010). In addition, Ely et al. (1991) found that the Tfm (Ar) rat, lacking functional $\mathrm{AR}$, and castrated rats have lower blood pressure than intact control rats, suggesting that androgen/AR signaling might be involved in hypertension. Although there are still few epidemiological studies showing opposite results that testosterone is inversely correlated with blood pressure in male populations (Barrett-Connor \& Khaw 1988, Khaw \& Barrett-Connor 1988, Svartberg et al. 2004), it is generally accepted that males have higher blood pressure than females.

In summary, androgen/AR signaling would worsen hypertension and treatment with anti-androgens might be able to suppress hypertension. However, anti-androgen treatment has several side effects, including reduction of libido and suppression of sexual activities. These side effects may stop men who have hypertension from taking such treatments. Although anti-androgen or even the recently developed anti-AR compounds may inhibit high blood pressure, there are still controversial observations showing that ARKO mice developed higher blood pressure than wild-type mice (Huang et al. 2015) and that castration failed to prevent prenatally programmed hypertension. These complex outcomes suggest that the AR in individual cell types related to hypertension may have independent roles in the development of hypertension and using floxed Ar mice to delete AR in selective cells (Yu et al. 2008, Wang et al. 2009, Lin et al. 2011) may be a good tool to further study the role of AR in hypertension.

\section{Androgen/AR roles in stroke}

Stroke is a rapid loss in brain function due to ischemia caused by blockage or hemorrhage of blood vessels. There are three different kinds of strokes. Ischemic strokes happen when the blood vessels that supply the brain are occluded with a thrombus, a situation causing shortage or absence of delivery of oxygen and nutrition to the brain. Intra-cerebral hemorrhages, generally the least treatable, most disabling, and highest cause of stroke death, occur when bleeding happens in the brain. Subarachnoid hemorrhages happen when blood spills into the subarachnoid spaces and is the least common type of stroke. Trauma and ruptured intracranial aneurysms account for $70-90 \%$ of subarachnoid strokes (Carwile et al. 2009).

Risk factors causing strokes include atherosclerosis, diabetes, gender, heart valve defects, and hypertension. Male stroke incidence rate is $33 \%$ and prevalence is $41 \%$ higher than female worldwide (Appelros et al. 2009). To account for this gender difference, the relationship between sex steroids and stroke has been discussed and analyzed in the cohort studies (Yeap et al. 2009, Morales 2010). Unexpectedly, the results showed that men with low testosterone levels had a higher incidence of stroke compared with those with normal testosterone levels. Another study also suggested that testosterone level is inversely associated with stroke severity and 6-month mortality (Jeppesen et al. 1996). In animal studies, it has been shown that testosterone helped with the functional recovery following stroke (Pan et al. 2005). Interestingly, treatment with high doses of testosterone worsened the stroke outcomes in the castrated mouse model and antiandrogen could reverse this exacerbated effect (Uchida et al. 2009). Other controversial outcomes have also been reported showing that testosterone increases lesion sizes in male rats with middle cerebral artery occlusions (Hawk et al. 1998, Yang et al. 2002). The treatment with the more potent androgen, dihydrotestosterone (DHT), exacerbated cerebral ischemia in male rats (Cheng et al. 2007). The effects of androgens on stroke are still controversial; thus, more comprehensive experiments will be needed in order to determine conclusive results of how androgens affect stroke.

In fact, controversial observations also occurred in patients with strokes. It has been reported that there is no difference regarding testosterone levels between post-stroke survival in young men and healthy men (Taggart et al. 1980). However, another study found that high endogenous testosterone increases the stroke incidence in children (Normann et al. 2009). In addition, prostate cancer patients treated with ADT also show the discrepancies in stroke. Gonadotropin-releasing hormone antagonist treatment increases stroke incidence; however, orchidectomy combined with androgen blockage and oral anti-androgen failed to show significant elevation in stroke incidence (Smith 2008, Keating et al. 2010, Azoulay et al. 2011, Collier et al. 2011).

From these controversial outcomes, it seems that androgens might affect stroke in differential ways

Published by Bioscientifica Ltd. 
depending on several factors, such as age, methods of treatment with androgens or anti-androgens, and experimental approaches. However, these could not account for androgen/AR signaling effects on stroke, as androgen mainly exerts effects through AR. Even though androgens could affect cellular behavior through nongenomic actions (Wang et al. 2001, Heinlein \& Chang 2002, Miyamoto et al. 2002, Walker 2003, Heinlein \& Chang 2004, Kang et al. 2004, Foradori et al. 2008), the effects of stroke should show consistencies, but not paradoxes. One of the possible explanations for the differential effects of androgens on stroke may be that the AR plays differential roles in individual cells, thus affecting stroke in various manners. It would be an interesting future direction for the use of floxed AR mice (Yu et al. 2008, Wang et al. 2009, Lin et al. 2011) to clarify AR roles in different kinds of cells that are involved in cerebral injury. In summary, AR plays either protective or deleterious roles on strokes, dependent on several different kinds of factors.

\section{Androgen/AR roles in atherosclerosis}

Atherosclerosis progression can be a chronic expansion of the arterial intima with lipids, cells, and extracellular matrix for many years to decades long. Although this process itself, due to preservation of the arterial lumen, rarely leads to major symptoms, a few of these lesions undergo necrotic breakdown, which involves acute occlusive luminal thrombosis leading to myocardial infarction, unstable angina, sudden cardiac death, and/or stroke (Wolf et al. 2002).

Atherosclerosis is characterized as an inflammatory disease linked to certain risk factors, such as dyslipidemia, hypertension, and cigarette smoking. Atherosclerotic plaque progression and vulnerability are influenced by plaque cell and lipid composition rather than by the extent of arterial stenosis (Liu et al. 2003, Wu \& von Eckardstein 2003, Kaufman \& Vermeulen 2005). Vulnerable plaques in the coronary arteries tend to have a thin fibrous cap and a large lipid core with high macrophage content (Kyle et al. 2001). These plaques reside almost entirely in the intravascular space and, as a result of compensatory expansion of the diseased artery, are typically not detected by conventional angiographic approaches. Indeed, the majority of coronary occlusions and myocardial infarctions evolve from areas characterized by previous angiography as being mildly to moderately stenotic (Svartberg et al. 2006).
Gender differences also occur in atherosclerosis (Sinning et al. 2011). Misuse or abuse of androgens in athletes would increase the incidence of CVDs including atherosclerosis (Liu et al. 2003). However, the effects of exogenous testosterone on atherosclerosis are reported controversial in animal atherosclerotic models. Considering the fact that males have a higher incidence of atherosclerosis than females, it was originally believed that androgens promote atherosclerosis development. However, recent studies indicated that the physiological levels of androgens may inhibit atherosclerosis development. In an epidemiological study, atherosclerosis was shown to be inversely correlated with testosterone levels in men (Svartberg et al. 2006). Prostate cancer patients treated with ADT showed increased atherosclerosis (Shahani et al. 2008) and DHT administration could suppress atherosclerosis through inhibiting foam cell formation (Qiu et al. 2010). In contrast, controversial results were reported showing beneficial effects of castration in cholesterol-fed male rabbits (Larsen et al. 1993, Bruck et al. 1997, Alexandersen et al. 1999, Hanke et al. 2001). Although some studies suggest that androgen treatment might inhibit atherosclerosis, estrogen generated from high doses of testosterone may influence atherosclerosis development (Kushwaha \& Hazzard 1981, Haarbo \& Christiansen 1996). Therefore, it may not be easy to conclude how androgen and AR affect atherosclerosis progression based on these results.

What is the role of AR in atherosclerosis? No previous studies adequately addressed the role of AR on atherosclerosis. Recently, apoplipoprotein $E$ (Apoe)-null and GARKO mice have been developed for the investigation of the effects of ARKO on atherosclerosis (Ikeda et al. 2009), and the results suggest that GARKO mice have worse atherosclerosis progression than control mice. Interestingly, another study explored low density lipoprotein receptor ( $L d l r$ )-null mice; with specific deletion of AR in selective cells, including monocytes/macrophages, endothelial cells, and smooth muscle cells, and found unexpected results (Huang et al. 2014). Knockout of AR in macrophages/ monocytes suppressed atherosclerosis in Ldlr-null mice; however, knockout of AR in endothelial cells and smooth muscle cells did not show significant differences in atherosclerosis (Huang et al. 2014). Although cell-specific AR may differentially modulate atherosclerosis, GARKO mice still developed worse atherosclerosis than control mice in this study. These contrasting results could be due to the differential impacts of the serum androgen and lipid levels in these types of ARKO mice. GARKO mice have little serum testosterone; however, mice with knockout of

Published by Bioscientifica Ltd 
AR in selective cells have nearly normal androgen levels. As low androgen levels have been strongly linked to lipid production, this dramatic androgen difference may cause substantial changes in lipid profiles to alter atherosclerosis. Indeed, a study challenged Tfm mice with androgens and found reduced fatty streak formation. This result suggests that androgens might suppress lipid formation through non-genomic actions, which are independent of the AR (Nettleship et al. 2007).

Considering the fact that targeting androgen might lead to elevated lipid profiles, targeting AR in selective cells may represent a better therapeutic approach in atherosclerosis. Having shown promising results from cellspecific ARKO mice in suppressing atherosclerotic plaques, it would be of great interest to investigate compounds that could target AR in specific cell types. In fact, there has been one compound, ASC-J9, that has been previously demonstrated to be able to target AR in specific cell types without inhibiting androgen levels and fertility (Yang et al. 2007), including prostate cancer, liver cancer, bladder cancer, kidney cancer, wound healing, and SBMA neuronal disease (Miyamoto et al. 2007, Yang et al. 2007, Lai et al. 2009, Yamashita et al. 2012, Izumi et al. 2013, Lai et al. 2013, Liang et al. 2014). ASC-J9 could degrade AR via interrupting AR interaction with selective AR co-regulators including ARA55 and ARA70 (Lai et al. 2013). Naked AR, after being disassociated from the AR co-regulators, may then become more vulnerable to be degraded by the proteasome machinery that involves the alteration of $\mathrm{E} 3$ ubiquitin protein ligase-dependent degradation (Liang et al.2014). Unlike the classic anti-androgens that have side effects on reducing libido and sexual ability, mice treated with ASC-J9 show normal sexual desire and fertility (Yang et al. 2007). Importantly, ASC-J9 treatment in mice with atherosclerosis results in some improvement of symptoms (Huang et al. 2014), suggesting the possibility of targeting AR in selective cells to restrict atherosclerosis progression.

In summary, the role of AR is distinctively different from androgens in atherosclerosis. As androgen deficiency would lead to elevated lipid profiles, targeting AR in selective cells without altering the androgen expressions may be a better strategy than targeting androgens in alleviating atherosclerosis.

\section{Androgen/AR roles in abdominal aortic aneurysm (AAA)}

An aneurysm has been defined as dilation of vessels and is a permanent dilation of $50 \%$ or more compared with the normal diameter of the vessel (Grange et al. 1997, Johnston et al. 2002). An AAA is specifically located in the lower section of the aorta. There are several risk factors linked to AAA, including male gender, atherosclerosis, hypertension, and genetic predisposition (Annambhotla et al. 2008, Weintraub 2009). Up-to-date, surgery is the only treatment and there is no effective medicine to treat AAA in patients (Greenhalgh \& Powell 2008). Early studies suggested that some molecular mediators and extracellular matrix-degrading proteinases, including INF $\gamma$, CXCL10, CCR2, JNK, TGF $\beta 1$, ERK, the matrix metalloproteinase (MMP) family, and angiotensins (Thompson \& Baxter 1999, Daugherty et al. 2001, Yoshimura et al. 2005, MacTaggart et al. 2007, King et al. 2009, Zhang et al. 2009, Habashi et al. 2011, Holm et al. 2011), might contribute to AAA progression. However, recent studies demonstrated that MMPs (especially MMP-2 and MMP-9) are highly expressed in human and experimental mouse models of AAA (Sakalihasan et al. 1996, Goodall et al. 2001, Longo et al. 2005, Pearce \& Shively 2006). Although MMPs might be the potential reason behind AAA development, the molecular mechanisms related to gender differences in AAA remain unclear.

Male gender is one of the risk factors involved in AAA initiation and progression. Males show higher mortality rate, rupture risk, and vessel dilation than females after surgical therapy (Katz et al. 1997, Forbes et al. 2006, Hannawa et al. 2009). Henriques et al. (2004) used angiotensin II-induced AAA mouse model to study the effects of sexual hormones on AAA initiation and progression and found that castration in male mice reduced AAA incidence from 85 to 18\%; however, ovariectomy did not alter AAA incidence in female mice. Similarly, another study shows that castration reduced AAA diameters, testosterone treatment restored aortic diameters to the extent before castration (Cho et al. 2009), and that ovariectomy did not alter the aortic diameters in female rats with AAA. Those studies suggested that androgen might play a dominant role in AAA initiation and progression, and this speculation is also supported by epidemiological studies, as males show higher incidence, mortality, and aortic diameter in AAA than females. Similarly, other studies used exogenous androgens to treat AAA mice and rats and found that this androgen treatment increases the AAA incidence in male and female mice as well as male rats (Henriques et al. 2008, Cho et al. 2009). Together, androgen/AR signaling stimulates AAA initiation and progression.

Published by Bioscientifica Ltd. 
To further separate androgen and AR effects on AAA development, Bourghardt et al. implanted testosterone pellets in GARKO-Apoe-null mice, and found that depletion of $\mathrm{AR}$ has protection effects on AAA development and androgen treatment could promote AAA development in WT mice, but not in GARKO mice (Bourghardt 2010). Another group also developed several cell-specific ARKO mice that had AR knocked out in myeloid lineage, smooth muscle cells, or endothelial cells with Apoe-null background (Kobayashi et al. 2003, Alva et al. 2006, Yu et al. 2011). These cellspecific ARKO mice were treated with angiotensin II to induce AAA formation, and the obtained results show that the GARKO mice did not develop AAA (Huang et al. 2015). Similar results were also observed in MARKO and SARKO mice, but not in EARKO mice (Huang et al. 2015), suggesting that AR might modulate AAA development through altering inflammation and integrity of the aortic wall. Nevertheless, results from these ARKO mouse studies concluded that AR signaling is essential in AAA development.

Mechanistically, AR modulates AAA formation through inflammation via elevating interleukin 1 alpha (IL-1 $\propto$ ) and fibrosis process via mediating transforming growth factor beta (TGF $\beta 1$ ). Although TGF $\beta 1$ has been recently proposed as a therapeutic approach in treating AAA progression, TGF $\beta 1$ has also been indicated as a deleterious factor in AAA development (King et al. 2009). Future studies would be needed in order to clarify the actual role of TGF $\beta 1$ in AAA development.

Actually, MARKO and SARKO mice do not have altered androgen levels and still show inhibition in AAA development and progression. In addition, GARKO mice showed complete abolishment in AAA incidence; however, castration in male mice showed around $20 \%$ incidence in AAA initiation. These intriguing results suggest that AR is indispensable in AAA development. It is interesting to see whether targeting AR with ASC-J9, the AR degradation enhancer, or other small molecular AR inhibitors has the therapeutic potential in treating AAA.

\section{Androgen/AR role in cardiac hypertrophy}

Cardiac hypertrophy is prevalent in a substantial portion of individuals with hypertension (Devereux et al. 1987, Kaplinsky 1994) and recognized as an independent risk factor for congestive heart failure and sudden cardiac death (Neyses \& Pelzer 1995). Extended cardiac fibrosis results in increased myocardial stiffness, causing ventricular dysfunction, and, ultimately, heart failure (Weber \& Brilla 1991).

Significant gender-related differences in CVDs were already described in earlier sections. Men are at greater risk for cardiac hypertrophy than age-matched women (Fiebach et al. 1990, Crabbe et al. 2003, Maron et al. 2003). It was reported that the male heart of many species is hypertrophied relative to the female heart. In addition, the difference in repolarization on the electrocardiogram (ECG) between men and women has suggested that women have a QT (QT interval is a measure of the time between the start of the $\mathrm{Q}$ wave and the end of the $\mathrm{T}$ wave) prolongation relative to men (Lepeschkin \& Surawicz 1953). The difference in QT duration is not evident before puberty; however, it was persistent after menopause (Alimurung et al. 1950, Rautaharju et al. 1992, Stramba-Badiale et al. 1995). Other factors can also modify disease outcome. Age is the most commonly reported factor that is associated with the extent and severity of left ventricular hypertrophy (Klues et al. 1995, Maron et al. 2003). Younger patients tend to have significantly more hypertrophy than older patients, and hypertrophy in older patients is generally more localized (Klues et al. 1995).

Despite the evident gender differences in cardiac phenotypes, which are probably dependent on sex hormones, little is known about the underlying mechanisms. Up-to-date, there has been no clear evidence that androgens can produce direct hypertrophic effects on cardiac myocytes independently from other neurohormonal or hemodynamic effects (Sadoshima \& Izumo 1993, Marsh et al. 1998). Nonetheless, the differences in hypertropic response with sex hormone treatments have been observed. Treatment with estrogens were shown to play a protective role in the hypertrophic response (Xin et al. 2002), whereas exposure of cardiac myocytes to androgens results in hypertrophy (Marsh et al. 1998). The results of both in vitro and in vivo studies indicate that sex hormones play a key role in the development of cardiac structural abnormalities. Estrogens showed anti-proliferative effects on cardiac fibroblasts (Dubey et al. 1998) and vascular smooth muscle cells (Chen et al. 1996, Somjen et al. 1998), whereas androgens increase proliferation of vascular smooth muscle cells (Fujimoto et al. 1994). Studies using sinoaortic denervation-induced cardiac hypertrophy in rats have also shown that testosterone facilitated hypertrophy while estrogen inhibited it (Cabral et al. 1988). However, a less severe model of cardiac hypertrophy in rats (swimmingor hypertension-induced) failed to confirm the

Published by Bioscientifica Ltd 
anti-proliferative effect of estrogen (Malhotra et al. 1990). Moreover, not all males developed gender-related cardiac abnormalities. Somjen et al. (1998) reported a biphasic proliferative response for both estrogen and testosterone in vascular smooth muscle and endothelial cells.

Mice lacking guanylyl cyclase A (GC-A), a natriuretic peptide receptor, exhibit salt-resistant hypertension, myocardial hypertrophy, interstitial fibrosis, and sudden death (before the age of 6 months) (Lopez et al. 1995). The male GC-A (Npr1) KO mice show more pronounced cardiac hypertrophy and fibrosis compared with the female $G C$ - $A$ KO mice, and these gender-related differences were not observed in wild-type (WT) mice. Additionally, these gender-related differences were attenuated either by castration or the treatment with the anti-androgen, flutamide, and were abolished by a genetic disruption of angiotensin (Ang) II type $1 \mathrm{~A}(\mathrm{AT} 1 \mathrm{~A})$ receptors in the male $G C$ - $A$ KO mice.

AR is present in the myocardial tissues (Marsh et al. 1998, Meyer et al. 1998, Weinberg et al. 1999), which allows androgens to modulate the cardiac phenotype and produce hypertrophy by direct receptor-specific mechanisms that are involved in the modulation of many genes (Morano et al. 1990, Towbin \& Lipshultz 1999). Marsh et al. (1998) investigated whether AR in myocytes could regulate cardiac hypertrophy by exogenous androgens treatments and found a significant hypertrophic response directly in cardiac myocytes. When they examined the hypertrophic response by using $\left[{ }^{3} \mathrm{H}\right]$ phenylalanine incorporation and atrial natriuretic peptide secretion as markers of hypertrophy in cultured rat myocytes, they found that both testosterone and DHT produced an AR-specific hypertrophic response in these cells. Importantly, DHT is the most active natural androgen, which is never aromatized to estrogen. So, it is evident that AR can modulate hypertrophic response in cardiac myocytes.

All together, men have increased cardiac hypertrophy compared with age-matched women and androgens would promote cardiac hypertrophy.

\section{Androgen/AR roles in heart failure}

Myocardial hypertrophy with hypertension represents a risk factor for congestive heart failure. Heart failure can also result from CADs and ischemia due to the potential mechanisms involved in maladaptive and prolonged neurohormonal and pro-inflammatory cytokine activation that result in a metabolic shift favoring catabolism and loss of skeletal muscle bulk and function (Malkin et al. 2006b).

Men have a higher incidence and severity of heart failures than women (Fairweather et al. 2008, Wexler et al. 2009, Regitz-Zagrosek et al. 2010). The incidence of myocarditis is higher in men than in women, and notably, gender difference in myocardial ischemia/ reperfusion injury has also been established (Wang et al. $2005 a, 2008)$. Indeed, some studies have clearly indicated that testosterone exacerbates ischemia/reperfusioninduced cardiac dysfunction and enhances myocardial inflammation and apoptotic signaling in male hearts (Cavasin et al. 2003, Wang et al. 2005b).

However, Pastor-Perez et al. (2011) investigated sex hormonal levels in men with chronic heart failure and found that $28 \%$ were deficient of testosterone, and less circulating testosterone levels in the body have been related to exercise capability in male patients with chronic heart failure (Manzano-Fernandez et al. 2011).

Recently, several reports of follow-up studies in prostate cancer patients who received ADT revealed that these patients have a higher risk of developing heart failure (Keating et al. 2006, Shahani et al. 2008, Keating et al. 2010, Chung et al. 2011, Martin-Merino et al. 2011, Nguyen et al. 2011, Collier et al. 2012) and cardiovascular mortality (Tsai et al. 2007), suggesting that loss of androgen might promote heart failure. In contrast, ART has been proposed to improve heart function (Malkin et al. 2006a,b), with the results showing a significant increase in cardiac output, and an improved functional capacity and symptoms of men with heart failure (Pugh et al. 2003, 2004, Malkin et al. $2006 \mathrm{~b}$ ). Other reports also suggested that androgen levels might also have an anti-ischemic effect on heart function improvement in clinics (Rosano et al. 1999, Webb et al. 1999a,b).

The underlying mechanisms of the androgen effects on heart failure remain unclear; however, a variety of processes related to cardiac function have been proposed. For example, androgen might be able to influence the contractile function of myocardium, endothelial function, and alterations in skeletal muscle (Vicencio et al. 2006, Malkin et al. 2009, Rowell et al. 2009). Androgen is also involved in nervous system development (Bialek et al. 2004), which could increase neuritic growth and synaptogenesis in both motor neurons of the spinal nucleus of the bulbocavernosus (Forger et al. 1992, Matsumoto 1997) and some pelvic autonomic neurons (Meusburger \& Keast 2001), as well as increase nerve growth factor levels in the brain (Tirassa et al. 1997).

Published by Bioscientifica Ltd 
It seems that both extreme high or low androgen levels increase the chance of heart failure. As it is well known that testosterone abuse in athletes significantly raises the chance of sudden heart failure and the recent epidemiology studies show that castrated prostate cancer patients have elevated risk of developing CVDs, suggesting the androgen levels might need to be balanced. Therefore, androgen/AR signaling might not be the suitable therapeutic target in heart failure patients.

\section{AR effects on the metabolic syndrome/ diabetes and their impacts on CVDs}

Earlier we discussed that several factors, such as smoking, hypertension, diabetes, and hyperlipidemia, can affect the occurrence of CVDs. These factors are also known to affect the metabolic syndromes (Julius et al. 1981, Schulze et al. 1981). It is well known that obese individuals are prone to develop more insulin resistance compared with non-obese individuals, as these individuals have higher chances of having metabolic risk factors, such as elevated circulating triglycerides (TGs), reduced highdensity lipoprotein cholesterol levels, elevated fasting blood glucose levels, and high blood pressure (Hu et al.
2004). These metabolic abnormalities in conjunction with abdominal obesity represent the classical symptoms of the metabolic syndrome. Therefore, CVDs are considered to be closely correlated with the metabolic syndrome.

Lin et al. investigated whether the androgen/AR affects the metabolic syndrome, by determining whether GARKO mice have variations in their lipid metabolism and insulin/leptin resistance. It was shown that the male GARKO mice have increased body weight gain compared with their WT littermate control mice (Lin et al. 2005). The observed obesity in GARKO male mice was shown to be associated with elevations of circulating TGs and free fatty acids, as well as lipid deposition in non-adipose tissue, including the liver and muscle (Lin et al. 2005). Consistent with the enlarged fat mass, circulating leptin was shown elevated in the GARKO male mice and was observed before the onset of obesity (Lin et al. 2005). These results suggest that global loss of AR increased circulating leptin levels independent of body fat accumulation.

Lin et al. further treated the GARKO mice and their WT littermates with DHT for analysis of several serum hormones and metabolic parameters. Surprisingly, DHT replacement could not reverse the metabolic abnormalities and insulin resistance in GARKO male mice (Lin et al. 2005), suggesting that the AR is critical in

Table 1 Summary of gender differences and androgen and anti-androgen treatments in cardiovascular diseases.

\begin{tabular}{|c|c|c|}
\hline CVDs & Gender difference & $\begin{array}{l}\text { Androgen or anti-androgen treatments in } \\
\text { clinical outcomes }\end{array}$ \\
\hline Hypertension & $\begin{array}{l}\text { Males have higher blood } \\
\text { pressure than females }\end{array}$ & $\begin{array}{l}\text { Androgen treatments increase blood } \\
\text { pressure in male patients }\end{array}$ \\
\hline Stroke & $\begin{array}{l}\text { Males have higher incidence in } \\
\text { stroke than females }\end{array}$ & $\begin{array}{l}\text { Gonadotropin-releasing hormone } \\
\text { agonist treatment increases stroke } \\
\text { incidence in prostate cancer patients, } \\
\text { but orchiectomy combined with } \\
\text { androgen blockage and oral anti- } \\
\text { androgen failed to show significant } \\
\text { elevation in stroke incidence }\end{array}$ \\
\hline Atherosclerosis & $\begin{array}{l}\text { Males have thicker intima- } \\
\text { media in early carotid } \\
\text { atherosclerosis than females }\end{array}$ & $\begin{array}{l}\text { Androgen deprivation therapy in } \\
\text { patients with prostate cancer resulted } \\
\text { in increased atherosclerosis }\end{array}$ \\
\hline $\begin{array}{l}\text { Abdominal aortic } \\
\text { aneurysm }\end{array}$ & $\begin{array}{l}\text { Males have higher incidence } \\
\text { than females }\end{array}$ & N/A \\
\hline Myocardial hypertrophy & $\begin{array}{l}\text { Males are at greater risk for } \\
\text { myocardial hypertrophy than } \\
\text { age-matched females }\end{array}$ & $\mathrm{N} / \mathrm{A}$ \\
\hline Myocardial infarction & $\begin{array}{l}\text { Females develop more severe } \\
\text { myocardial infarction than } \\
\text { males }\end{array}$ & $\begin{array}{l}\text { Gonadotropin-releasing hormone } \\
\text { agonist treatment increases the risk of } \\
\text { incident myocardial infarction and } \\
\text { sudden cardiac death }\end{array}$ \\
\hline
\end{tabular}

\section{References}

Devereux et al. (1987),

Daugherty et al. (2001),

Dunajska et al. (2004),

Collier et al. (2012)

Julius et al. (1981), Kannel

(2000), Wang et al. (2005),

Kang et al. (2012),

Zimmerman (2012)

Alimurung et al. (1950), Kyle et al. (2001), King et al. (2009), Lai et al. (2009)

Neyses \& Pelzer (1995), Nettleship et al. (2007), Nguyen et al. (2011)

Reckelhoff (2001), Reckelhoff et al. (2005), Lai et al. (2009)

Walker (2003), Vigna \& Bergami (2005), Wang et al. (2005a), Lai et al. (2009), Razzak (2012)

N/A, data not available. 


$\begin{array}{lll}\text { Myocardial infarction (MI) } & \text { Stroke } & \text { Hypertension } \\ \text { GARKO } & \text { GARKO } & \text { Androgen } \\ \text { MI } & \text { Stroke } & \text { Hypertension }\end{array}$

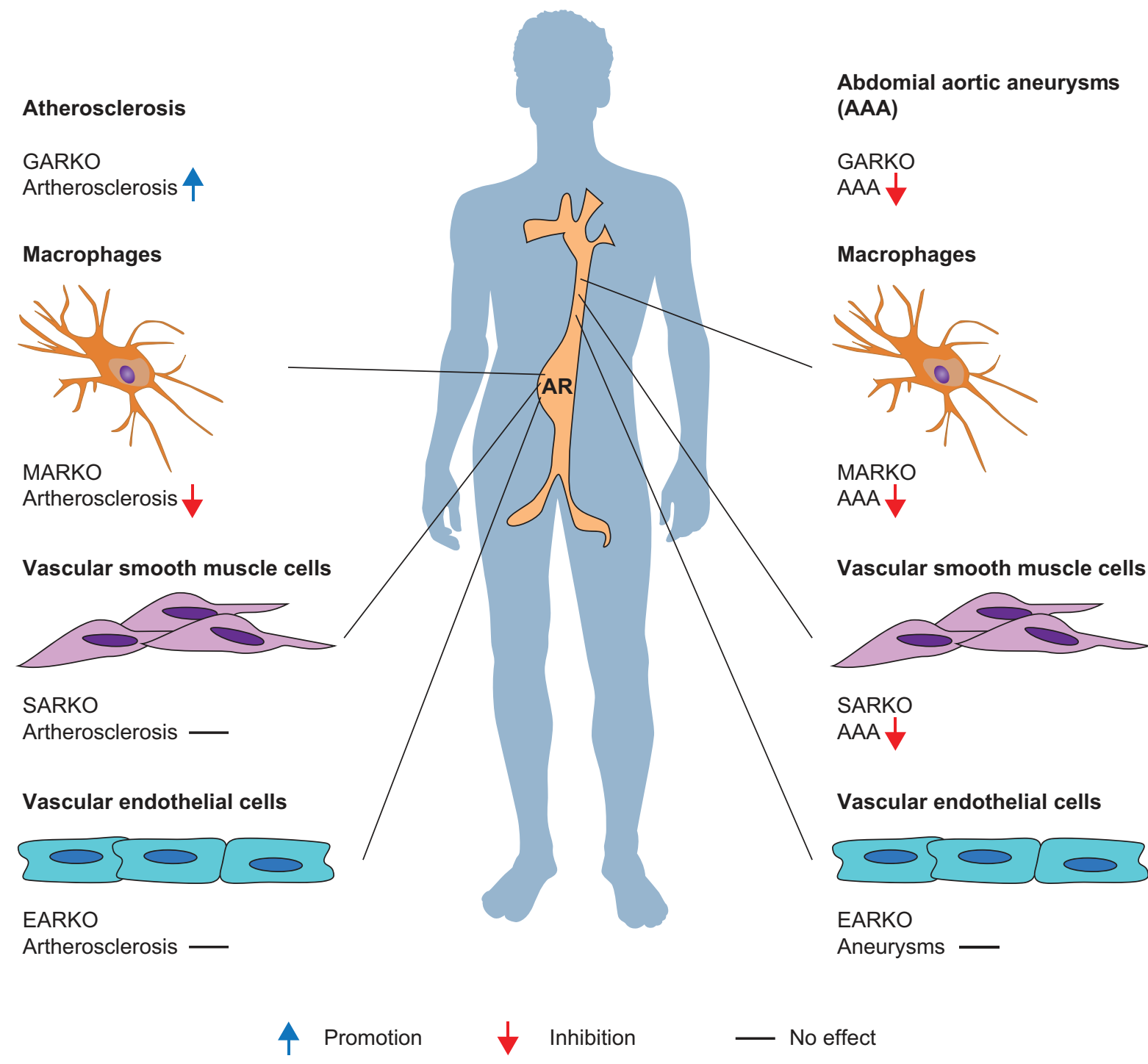

GARKO, General androgen receptor knockout; MARKO, macrophage specific androgen receptor knockout;

SARKO, smooth muscle cell specific androgen receptor knockout; EARKO, endothelial cell specific androgen receptor knockout

Figure 1

The impact of knocking out cell-specific AR on the development and progression of CVDs. A full colour version of this figure is available at http://dx.doi. org/10.1530/JOE-15-0518

mediating the effects of androgens to regulate glucose and lipid metabolisms in males.

From these results, it was concluded that visceral obesity and progressive insulin resistance are two major abnormalities linked to the metabolic syndrome. Lin et al. (Hoesche et al. 1993, Lin et al. 2008) further developed tissue-specific ARKO mouse models, including liver-specific
(LARKO) and NARKO mice, as these organs are considered to be critical in these two processes. They were then able to evaluate the effect of AR in these specific tissues on the metabolic syndrome. The LARKO mice were developed using albumin-Cre mice and fed a high-fat diet (HFD) and mice were shown to weigh $13 \%$ more then their WT littermates (Lin et al. 2008), suggesting that the LARKO mice

Published by Bioscientifica Ltd 
were more susceptible to diet-induced obesity. The LARKO mice fed HFD exhibited impaired glucose metabolism due to the developed insulin resistance (Lin et al. 2008).

Interestingly, several groups demonstrated that there are differential insulin sensitivities in the male and female central nervous system (Obici \& Rossetti 2003, Schwartz \& Porte 2005, Clegg et al. 2006). The NARKO mice were developed using synapsin I-Cre mice (Hoesche et al. 1993), and the NARKO male mice displayed increased body weight with increased visceral adiposity, hyperinsulinemia, hyperglycemia, and increased hepatic glucose projection. In addition, the NARKO mice exhibited impaired insulin responsiveness in the hypothalamus (Yu et al. 2013).

From these studies of global ARKO mice and tissuespecific ARKO mice, it can be concluded that AR plays an important role in contributing to the obesity and insulin/ leptin resistance and can therefore increase the metabolic syndromes in mice.

\section{Summary}

CVDs are related to each other and have common features. They all show gender differences (Table 1); however, the results of the androgen therapies, either ADT or ART, applied in all CVDs are not conclusive. Even whether the roles of androgens are protective or deleterious are not conclusive. In addition to this inconsistency, modulating body androgen levels is expected to cause many other side effects. So, it seems essential to develop another strategy of targeting androgen/AR for better treating the CVDs. It may be the time to turn our focus to target the AR rather than androgens. The therapy of targeting AR in selective cells might have several advantages over androgen therapy: (1) it will not affect whole-body androgen levels, thereby can avoid unwanted side effects; (2) it may not affect body lipid profiles, which can affect some CVDs; (3) we may target AR in selective cell types, not the whole body; and (4) we may also target the non-androgenmediated AR action.

The results of targeting $\mathrm{AR}$ in atherosclerosis and AAA using cell-specific ARKO mouse models indicate that targeting AR is indeed a better approach to battle these diseases (Fig. 1). Obvious improvement in AAA in the GARKO mice was observed. Interestingly, it was found that the ARKO effect on the total body was opposite to the monocyte/macrophages-specific ARKO effect on atherosclerosis. This result implies that AR contribution in each cell type in each disease might be different.
Taken together, targeting AR, instead of androgens, emerges as a new therapeutic approach in CVDs. However, the most critical point is how to apply this concept into clinical approach to target AR in specific cell types in CVDs. The use of the specific AR degradation enhancer, ASC-J9, or other newly developed small molecules that target AR may make it possible to target AR in specific cell types without affecting body androgen levels, thus reducing the development of the unwanted side effects.

\section{Declaration of interest}

The authors declare that there is no conflict of interest that could be perceived as prejudicing the impartiality of this review.

\section{Disclosure}

ASC-J9 ${ }^{\circledR}$ was patented by the University of Rochester, the University of North Carolina, and AndroScience, and then licensed to AndroScience. Both the University of Rochester and C.C. own royalties and equity in AndroScience.

\section{Funding}

This work did not receive any specific grant from any funding agency in the public, commercial, or not-for-profit sector.

\section{Acknowledgments}

This work was supported by NIH grant CA156700 and George Whipple Professorship Endowment, Taiwan Department of Health Clinical Trial and Research Center of Excellence grant DOH99-TD-B-111-004 (China Medical University, Taichung, Taiwan), and Tianjin Nature Science Grant 11 JCYBJC28400.

\section{References}

Alexandersen P, Haarbo J, Byrjalsen I, Lawaetz H \& Christiansen C 1999 Natural androgens inhibit male atherosclerosis: a study in castrated, cholesterol-fed rabbits. Circulation Research 84 813-819. (doi:10.1161/01.RES.84.7.813)

Alimurung MM, Joseph LG, Craige E \& Massell BF 1950 The Q-T interval in normal infants and children. Circulation 1 1329-1337. (doi:10.1161/01.CIR.1.6.1329)

Alva JA, Zovein AC, Monvoisin A, Murphy T, Salazar A, Harvey NL, Carmeliet P \& Iruela-Arispe ML 2006 VE-cadherin-Cre-recombinase transgenic mouse: a tool for lineage analysis and gene deletion in endothelial cells. Developmental Dynamics 235 759-767. (doi:10.1002/dvdy.20643)

Anderson GL, Limacher M, Assaf AR, Bassford T, Beresford SA, Black H, Bonds D, Brunner R, Brzyski R, Caan B, et al. 2004 Effects of conjugated equine estrogen in postmenopausal women with hysterectomy: the Women's Health Initiative randomized controlled trial. JAMA 291 1701-1712. (doi:10.1001/jama.291.14.1701)

Annambhotla S, Bourgeois S, Wang X, Lin PH, Yao Q \& Chen C 2008 Recent advances in molecular mechanisms of abdominal

Published by Bioscientifica Ltd.
(C) 2016 Society for Endocrinology Printed in Great Britain 
aortic aneurysm formation. World Journal of Surgery 32 976-986. (doi:10.1007/s00268-007-9456-x)

Appelros P, Stegmayr B \& Terent A 2009 Sex differences in stroke epidemiology: a systematic review. Stroke 40 1082-1090. (doi:10.1161/STROKEAHA.108.540781)

Ashton N \& Balment RJ 1991 Sexual dimorphism in renal function and hormonal status of New Zealand genetically hypertensive rats. Acta Endocrinologica 124 91-97. (doi:10.1530/acta.0.1240091)

Azoulay L, Yin H, Benayoun S, Renoux C, Boivin JF \& Suissa S 2011 Androgen-deprivation therapy and the risk of stroke in patients with prostate cancer. European Urology 60 1244-1250. (doi:10.1016/ j.eururo.2011.08.041)

Baltatu O, Cayla C, Iliescu R, Andreev D, Jordan C \& Bader M 2002 Abolition of hypertension-induced end-organ damage by androgen receptor blockade in transgenic rats harboring the mouse ren-2 gene. Journal of the American Society of Nephrology 13 2681-2687. (doi:10.1097/01.ASN.0000033327.65390.CA)

Banos G, Guarner V \& Perez-Torres I 2011 Sex steroid hormones, cardiovascular diseases and the metabolic syndrome. Cardiovascular \& Hematological Agents in Medicinal Chemistry 9 137-146. (doi:10.2174/187152511797037547)

Barrett-Connor E \& Khaw KT 1988 Endogenous sex hormones and cardiovascular disease in men. A prospective population-based study. Circulation 78 539-545. (doi:10.1161/01.CIR.78.3.539)

Bialek M, Zaremba P, Borowicz KK \& Czuczwar SJ 2004 Neuroprotective role of testosterone in the nervous system. Polish Journal of Pharmacology 56 509-518.

Bourghardt J 2010 Actions of androgens and estrogens in experimental models of cardiovascular disease. Doctoral Thesis, University of Gothenburg.

Bruck B, Brehme U, Gugel N, Hanke S, Finking G, Lutz C, Benda N, Schmahl FW, Haasis R \& Hanke H 1997 Gender-specific differences in the effects of testosterone and estrogen on the development of atherosclerosis in rabbits. Arteriosclerosis, Thrombosis, and Vascular Biology 17 2192-2199. (doi:10.1161/01.ATV.17.10.2192)

Burt VL, Whelton P, Roccella EJ, Brown C, Cutler JA, Higgins M, Horan MJ \& Labarthe D 1995 Prevalence of hypertension in the US adult population. Results from the Third National Health and Nutrition Examination Survey, 1988-1991. Hypertension 25 305-313. (doi:10.1161/01.HYP.25.3.305)

Cabral AM, Vasquez EC, Moyses MR \& Antonio A 1988 Sex hormone modulation of ventricular hypertrophy in sinoaortic denervated rats. Hypertension 11 I93-I97.

Carwile E, Wagner AK, Crago E \& Alexander SA 2009 Estrogen and stroke: a review of the current literature. Journal of Neuroscience Nursing $\mathbf{4 1}$ 18-25. (doi:10.1097/JNN.0b013e31819345f8)

Cavasin MA, Sankey SS, Yu AL, Menon S \& Yang XP 2003 Estrogen and testosterone have opposing effects on chronic cardiac remodeling and function in mice with myocardial infarction. American Journal of Physiology: Heart and Circulatory Physiology 284 H1560-H1569. (doi:10.1152/ajpheart.01087.2002)

Chen YF \& Meng QC 1991 Sexual dimorphism of blood pressure in spontaneously hypertensive rats is androgen dependent. Life Sciences 48 85-96. (doi:10.1016/0024-3205(91)90428-E)

Chen SJ, Li H, Durand J, Oparil S \& Chen YF 1996 Estrogen reduces myointimal proliferation after balloon injury of rat carotid artery. Circulation 93 577-584. (doi:10.1161/01.CIR.93.3.577)

Cheng J, Alkayed NJ \& Hurn PD 2007 Deleterious effects of dihydrotestosterone on cerebral ischemic injury. Journal of Cerebral Blood Flow \& Metabolism 27 1553-1562. (doi:10.1038/sj.jcbfm.9600457)

Cho BS, Woodrum DT, Roelofs KJ, Stanley JC, Henke PK \& Upchurch GR Jr 2009 Differential regulation of aortic growth in male and female rodents is associated with AAA development. Journal of Surgical Research 155 330-338. (doi:10.1016/j.jss.2008.07.027)

Chung SD, Chen YK, Wu FJ \& Lin HC 2011 Hormone therapy for prostate cancer and the risk of stroke: a 5-year follow-up study. BJU International 109 1001-1005. (doi:10.1111/j.1464-410X.2011.10459.x)
Clegg DJ, Brown LM, Woods SC \& Benoit SC 2006 Gonadal hormones determine sensitivity to central leptin and insulin. Diabetes $\mathbf{5 5}$ 978-987.(doi:10.2337/diabetes.55.04.06.db05-1339)

Collier A, Ghosh S, McGlynn B \& Hollins G 2011 Prostate cancer, androgen deprivation therapy, obesity, the metabolic syndrome, type 2 diabetes, and cardiovascular disease: a review. American Journal of Clinical Oncology 35 504-509. (doi:10.1097/ COC.0b013e318201a406)

Collier A, Ghosh S, McGlynn B \& Hollins G 2012 Prostate cancer, androgen deprivation therapy, obesity, the metabolic syndrome, type 2 diabetes, and cardiovascular disease: a review. American Journal of Clinical Oncology 35 504-509. (doi:10.1097/ COC.0b013e318201a406)

Crabbe DL, Dipla K, Ambati S, Zafeiridis A, Gaughan JP, Houser SR \& Margulies KB 2003 Gender differences in post-infarction hypertrophy in end-stage failing hearts. Journal of the American College of Cardiology 41 300-306. (doi:10.1016/S0735-1097(02)02710-9)

Daugherty A, Manning MW \& Cassis LA 2001 Antagonism of AT2 receptors augments angiotensin II-induced abdominal aortic aneurysms and atherosclerosis. British Journal of Pharmacology 134 865-870. (doi:10.1038/sj.bjp.0704331)

Devereux RB, Pickering TG, Alderman MH, Chien S, Borer JS \& Laragh JH 1987 Left ventricular hypertrophy in hypertension. Prevalence and relationship to pathophysiologic variables. Hypertension 9 II53-II60.

Dubey RK, Gillespie DG, Jackson EK \& Keller PJ 1998 17Beta-estradiol, its metabolites, and progesterone inhibit cardiac fibroblast growth. Hypertension 31 522-528. (doi:10.1161/01.HYP.31.1.522)

Dunajska K, Milewicz A, Szymczak J, Jedrzejuk D, Kuliczkowski W, Salomon P \& Nowicki P 2004 Evaluation of sex hormone levels and some metabolic factors in men with coronary atherosclerosis. Aging Male 7 197-204. (doi:10.1080/13685530400004181)

Egan BM, Zhao Y \& Axon RN 2010 US trends in prevalence, awareness, treatment, and control of hypertension, 1988-2008. JAMA 303 2043-2050. (doi:10.1001/jama.2010.650)

Ely DL, Salisbury R, Hadi D, Turner M \& Johnson ML 1991 Androgen receptor and the testes influence hypertension in a hybrid rat model. Hypertension 17 1104-1110. (doi:10.1161/ 01.HYP.17.6.1104)

Fairweather D, Frisancho-Kiss S \& Rose NR 2008 Sex differences in autoimmune disease from a pathological perspective. American Journal of Pathology 173 600-609. (doi:10.2353/ajpath.2008.071008)

Fiebach NH, Viscoli CM \& Horwitz RI 1990 Differences between women and men in survival after myocardial infarction. Biology or methodology? JAMA 263 1092-1096. (doi:10.1001/ jama.1990.03440080070026)

Foradori CD, Weiser MJ \& Handa RJ 2008 Non-genomic actions of androgens. Frontiers in Neuroendocrinology 29 169-181. (doi:10.1016/j.yfrne.2007.10.005)

Forbes TL, Lawlor DK, DeRose G \& Harris KA 2006 Gender differences in relative dilatation of abdominal aortic aneurysms. Annals of Vascular Surgery 20 564-568. (doi:10.1007/S10016-006-9079-y)

Forger NG, Hodges LL, Roberts SL \& Breedlove SM 1992 Regulation of motoneuron death in the spinal nucleus of the bulbocavernosus. Journal of Neurobiology 23 1192-1203.

Fujimoto R, Morimoto I, Morita E, Sugimoto H, Ito Y \& Eto S 1994 Androgen receptors, 5 alpha-reductase activity and androgendependent proliferation of vascular smooth muscle cells. Journal of Steroid Biochemistry and Molecular Biology 50 169-174. (doi:10.1016/0960-0760(94)90025-6)

Ganten U, Schroder G, Witt M, Zimmermann F, Ganten D \& Stock G 1989 Sexual dimorphism of blood pressure in spontaneously hypertensive rats: effects of anti-androgen treatment. Journal of Hypertension 7 721-726.

Gaziano TA, Bitton A, Anand S, Abrahams-Gessel S \& Murphy A 2010 Growing epidemic of coronary heart disease in low- and middle-income countries. Current Problems in Cardiology 35 72-115. (doi:10.1016/j.cpcardiol.2009.10.002)

Published by Bioscientifica Ltd. 
Goodall S, Crowther M, Hemingway DM, Bell PR \& Thompson MM 2001 Ubiquitous elevation of matrix metalloproteinase-2 expression in the vasculature of patients with abdominal aneurysms. Circulation 104 304-309. (doi:10.1161/01.CIR.104.3.304)

Grange JJ, Davis V \& Baxter BT 1997 Pathogenesis of abdominal aortic aneurysm: an update and look toward the future. Cardiovascular Surgery 5 256-265. (doi:10.1016/S0967-2109(97)00018-5)

Greenhalgh RM \& Powell JT 2008 Endovascular repair of abdominal aortic aneurysm. New England Journal of Medicine 358 494-501. (doi:10.1056/NEJMct0707524)

Haarbo J \& Christiansen C 1996 The impact of female sex hormones on secondary prevention of atherosclerosis in ovariectomized cholesterol-fed rabbits. Atherosclerosis 123 139-144. (doi:10.1016/0021-9150(96)05798-X)

Habashi JP, Doyle JJ, Holm TM, Aziz H, Schoenhoff F, Bedja D, Chen Y, Modiri AN, Judge DP \& Dietz HC 2011 Angiotensin II type 2 receptor signaling attenuates aortic aneurysm in mice through ERK antagonism. Science 332 361-365. (doi:10.1126/science.1192152)

Hanke H, Lenz C, Hess B, Spindler KD \& Weidemann W 2001 Effect of testosterone on plaque development and androgen receptor expression in the arterial vessel wall. Circulation 103 1382-1385. (doi:10.1161/01.CIR.103.10.1382)

Hannawa KK, Eliason JL \& Upchurch GR Jr 2009 Gender differences in abdominal aortic aneurysms. Vascular 17 (Supplement 1) S30-S39. (doi:10.2310/6670.2008.00092)

Hawk T, Zhang YQ, Rajakumar G, Day AL \& Simpkins JW 1998 Testosterone increases and estradiol decreases middle cerebral artery occlusion lesion size in male rats. Brain Research 796 296-298. (doi:10.1016/S0006-8993(98)00327-8)

Heinlein CA \& Chang C 2002 The roles of androgen receptors and androgen-binding proteins in nongenomic androgen actions. Molecular Endocrinology 16 2181-2187. (doi:10.1210/me.2002-0070)

Heinlein CA \& Chang C 2004 Androgen receptor in prostate cancer. Endocrine Reviews 25 276-308. (doi:10.1210/er.2002-0032)

Henriques TA, Huang J, D'Souza SS, Daugherty A \& Cassis LA 2004 Orchidectomy, but not ovariectomy, regulates angiotensin II-induced vascular diseases in apolipoprotein E-deficient mice. Endocrinology 145 3866-3872. (doi:10.1210/en.2003-1615)

Henriques T, Zhang X, Yiannikouris FB, Daugherty A \& Cassis LA 2008 Androgen increases AT1a receptor expression in abdominal aortas to promote angiotensin II-induced AAAs in apolipoprotein E-deficient mice. Arteriosclerosis, Thrombosis, and Vascular Biology 28 1251-1256. (doi:10.1161/ATVBAHA.107.160382)

Hoesche C, Sauerwald A, Veh RW, Krippl B \& Kilimann MW 1993 The 5 '-flanking region of the rat synapsin I gene directs neuronspecific and developmentally regulated reporter gene expression in transgenic mice. Journal of Biological Chemistry 268 26494-26502.

Holm TM, Habashi JP, Doyle JJ, Bedja D, Chen Y, van Erp C, Lindsay ME, Kim D, Schoenhoff F, Cohn RD, et al. 2011 Noncanonical TGFbeta signaling contributes to aortic aneurysm progression in Marfan syndrome mice. Science 332 358-361. (doi:10.1126/science.1192149)

Hu G, Qiao Q, Tuomilehto J, Balkau B, Borch-Johnsen K \& Pyorala K 2004 Prevalence of the metabolic syndrome and its relation to all-cause and cardiovascular mortality in nondiabetic European men and women. Archives of Internal Medicine 164 1066-1076. (doi:10.1001/ archinte.164.10.1066)

Hu X, Rui L, Zhu T, Xia H, Yang X, Wang X, Liu H, Lu Z \& Jiang H 2011 Low testosterone level in middle-aged male patients with coronary artery disease. European Journal of Internal Medicine 22 e133-e136. (doi:10.1016/j.ejim.2011.08.016)

Hu JC, Williams SB, O’Malley AJ, Smith MR, Nguyen PL \& Keating NL 2012 Androgen-deprivation therapy for nonmetastatic prostate cancer is associated with an increased risk of peripheral arterial disease and venous thromboembolism. European Urology 61 1119-1128. (doi:10.1016/j.eururo.2012.01.045)
Huang CK, Pang H, Wang L, Niu Y, Luo J, Chang E, Sparks JD, Lee SO \& Chang C 2014 New therapy via targeting androgen receptor in monocytes/macrophages to battle atherosclerosis. Hypertension 63 1345-1353. (doi:10.1161/HYPERTENSIONAHA.113.02804)

Huang CK, Luo J, Lai KP, Wang R, Pang H, Chang E, Yan C, Sparks J, Lee SO, Cho J, et al. 2015 Androgen receptor promotes abdominal aortic aneurysm development via modulating inflammatory interleukin-1alpha and transforming growth factor-beta1 expression. Hypertension 66 881-891. (doi:10.1161/ HYPERTENSIONAHA.115.05654)

Hulley S, Grady D, Bush T, Furberg C, Herrington D, Riggs B \& Vittinghoff E 1998 Randomized trial of estrogen plus progestin for secondary prevention of coronary heart disease in postmenopausal women. Heart and Estrogen/progestin Replacement Study (HERS) Research Group. JAMA 280 605-613. (doi:10.1001/jama.280.7.605)

Iams SG, McMurthy JP \& Wexler BC 1979 Aldosterone, deoxycorticosterone, corticosterone, and prolactin changes during the lifespan of chronically and spontaneously hypertensive rats. Endocrinology 104 1357-1363. (doi:10.1210/endo-104-5-1357)

Ikeda Y, Aihara K, Yoshida S, Sato T, Yagi S, Iwase T, Sumitomo Y, Ise T, Ishikawa K, Azuma H, et al. 2009 Androgen-androgen receptor system protects against angiotensin II-induced vascular remodeling. Endocrinology 150 2857-2864. (doi:10.1210/en.2008-1254)

Izumi K, Fang LY, Mizokami A, Namiki M, Li L, Lin WJ \& Chang C 2013 Targeting the androgen receptor with siRNA promotes prostate cancer metastasis through enhanced macrophage recruitment via CCL2/CCR2-induced STAT3 activation. EMBO Molecular Medicine 5 1383-1401. (doi:10.1002/emmm.201202367)

Jeppesen LL, Jorgensen HS, Nakayama H, Raaschou HO, Olsen TS \& Winther K 1996 Decreased serum testosterone in men with acute ischemic stroke. Arteriosclerosis, Thrombosis, and Vascular Biology 16 749-754. (doi:10.1161/01.ATV.16.6.749)

Johnston SC, Higashida RT, Barrow DL, Caplan LR, Dion JE, Hademenos G, Hopkins LN, Molyneux A, Rosenwasser RH, Vinuela F, et al. 2002 Recommendations for the endovascular treatment of intracranial aneurysms: a statement for healthcare professionals from the Committee on Cerebrovascular Imaging of the American Heart Association Council on Cardiovascular Radiology. Stroke 33 2536-2544. (doi:10.1161/ 01.STR.0000034708.66191.7D)

Julius U, Leonhardt W, Schulze J, Schollberg K, Hanefeld M \& Haller H 1981 Hyperinsulinemia in patients with low fractional catabolic rate of triglycerides. Acta Diabetologica Latina 18 217-223. (doi:10.1007/BF02047893)

Kang HY, Cho CL, Huang KL, Wang JC, Hu YC, Lin HK, Chang C \& Huang KE 2004 Nongenomic androgen activation of phosphatidylinositol 3-kinase/Akt signaling pathway in MC3T3-E1 osteoblasts. Journal of Bone and Mineral Research 19 1181-1190. (doi:10.1359/JBMR.040306)

Kang NN, Fu L, Xu J, Han Y, Cao JX, Sun JF \& Zheng M 2012 Testosterone improves cardiac function and alters angiotensin II receptors in isoproterenol-induced heart failure. Archives of Cardiovascular Diseases 105 68-76. (doi:10.1016/j.acvd.2011.12.002)

Kannel WB 2000 Elevated systolic blood pressure as a cardiovascular risk factor. American Journal of Cardiology 85 251-255. (doi:10.1016/ S0002-9149(99)00635-9)

Kaplinsky E 1994 Significance of left ventricular hypertrophy in cardiovascular morbidity and mortality. Cardiovascular Drugs and Therapy 8 (Supplement 3) 549-556. (doi:10.1007/BF00877223)

Katz DJ, Stanley JC \& Zelenock GB 1997 Gender differences in abdominal aortic aneurysm prevalence, treatment, and outcome. Journal of Vascular Surgery 25 561-568. (doi:10.1016/S0741-5214(97)70268-4)

Kaufman JM \& Vermeulen A 2005 The decline of androgen levels in elderly men and its clinical and therapeutic implications. Endocrine Reviews 26 833-876. (doi:10.1210/er.2004-0013) http://joe.endocrinology-journals.org

DOI: $10.1530 / J O E-15-0518$
(C) 2016 Society for Endocrinology Printed in Great Britain 
Keating NL, O'Malley AJ \& Smith MR 2006 Diabetes and cardiovascular disease during androgen deprivation therapy for prostate cancer. Journal of Clinical Oncology 24 4448-4456. (doi:10.1200/JCO.2006.06.2497)

Keating NL, O'Malley AJ, Freedland SJ \& Smith MR 2010 Diabetes and cardiovascular disease during androgen deprivation therapy: observational study of veterans with prostate cancer. Journal of the National Cancer Institute 102 39-46. (doi:10.1093/jnci/djp404)

Khaw KT \& Barrett-Connor E 1988 Blood pressure and endogenous testosterone in men: an inverse relationship. Journal of Hypertension 6 329-332.

Khoury S, Yarows SA, O’Brien TK \& Sowers JR 1992 Ambulatory blood pressure monitoring in a nonacademic setting. Effects of age and sex. American Journal of Hypertension 5 616-623. (doi:10.1093/ajh/5.9.616)

King VL, Lin AY, Kristo F, Anderson TJ, Ahluwalia N, Hardy GJ, Owens AP III, Howatt DA, Shen D, Tager AM, et al. 2009 Interferongamma and the interferon-inducible chemokine CXCL10 protect against aneurysm formation and rupture. Circulation 119 426-435. (doi:10.1161/CIRCULATIONAHA.108.785949)

Klues HG, Schiffers A \& Maron BJ 1995 Phenotypic spectrum and patterns of left ventricular hypertrophy in hypertrophic cardiomyopathy: morphologic observations and significance as assessed by two-dimensional echocardiography in 600 patients. Journal of the American College of Cardiology 26 1699-1708. (doi:10.1016/0735-1097(95)00390-8)

Kobayashi M, Kweon MN, Kuwata H, Schreiber RD, Kiyono H, Takeda K \& Akira S 2003 Toll-like receptor-dependent production of IL-12p40 causes chronic enterocolitis in myeloid cell-specific Stat3-deficient mice. Journal of Clinical Investigation 111 1297-1308. (doi:10.1172/ JCI17085)

Kushwaha RS \& Hazzard WR 1981 Exogenous estrogens attenuate dietary hypercholesterolemia and atherosclerosis in the rabbit. Metabolism 30 359-366. (doi:10.1016/0026-0495(81)90116-5)

Kyle UG, Genton L, Hans D, Karsegard L, Slosman DO \& Pichard C 2001 Age-related differences in fat-free mass, skeletal muscle, body cell mass and fat mass between 18 and 94 years. European Journal of Clinical Nutrition 55 663-672. (doi:10.1038/sj.ejcn.1601198)

Lai JJ, Lai KP, Chuang KH, Chang P, Yu IC, Lin WJ \& Chang C 2009 Monocyte/macrophage androgen receptor suppresses cutaneous wound healing in mice by enhancing local TNF-alpha expression. Journal of Clinical Investigation 119 3739-3751. (doi:10.1172/ JCI39335)

Lai KP, Huang CK, Chang YJ, Chung CY, Yamashita S, Li L, Lee SO, Yeh S \& Chang C 2013 New therapeutic approach to suppress castrationresistant prostate cancer using ASC-J9 via targeting androgen receptor in selective prostate cells. American Journal of Pathology 182 460-473. (doi:10.1016/j.ajpath.2012.10.029)

Larsen BA, Nordestgaard BG, Stender S \& Kjeldsen K 1993 Effect of testosterone on atherogenesis in cholesterol-fed rabbits with similar plasma cholesterol levels. Atherosclerosis 99 79-86. (doi:10.1016/0021-9150(93)90053-W)

Laughlin GA, Barrett-Connor E \& Bergstrom J 2008 Low serum testosterone and mortality in older men. Journal of Clinical Endocrinology \& Metabolism 93 68-75. (doi:10.1210/jc.2007-1792)

Lepeschkin E \& Surawicz B 1953 The duration of the Q-U interval and its components in electrocardiograms of normal persons. American Heart Journal 46 9-20. (doi:10.1016/0002-8703(53)90237-3)

Li Y, Kishimoto I, Saito Y, Harada M, Kuwahara K, Izumi T, Hamanaka I, Takahashi N, Kawakami R, Tanimoto K, et al. 2004 Androgen contributes to gender-related cardiac hypertrophy and fibrosis in mice lacking the gene encoding guanylyl cyclase-A. Endocrinology 145 951-958. (doi:10.1210/en.2003-0816)

Liang L, Li L, Tian J, Lee SO, Dang Q, Huang CK, Yeh S, Erturk E, Bushinsky D, Chang LS, et al. 2014 Androgen receptor enhances kidney stone-CaOx crystal formation via modulation of oxalate biosynthesis \& oxidative stress. Molecular Endocrinology 28 1291-1303. (doi:10.1210/me.2014-1047)
Lin HY, Xu Q, Yeh S, Wang RS, Sparks JD \& Chang C 2005 Insulin and leptin resistance with hyperleptinemia in mice lacking androgen receptor. Diabetes 54 1717-1725. (doi:10.2337/diabetes.54.6.1717)

Lin HY, Yu IC, Wang RS, Chen YT, Liu NC, Altuwaijri S, Hsu CL, Ma WL, Jokinen J, Sparks JD, et al. 2008 Increased hepatic steatosis and insulin resistance in mice lacking hepatic androgen receptor. Hepatology $\mathbf{4 7}$ 1924-1935. (doi:10.1002/hep.22252)

Lin TH, Yeh S \& Chang C 2011 Tissue-specific knockout of androgen receptor in mice. Methods in Molecular Biology 776 275-293. (doi:10.1007/978-1-61779-243-4_16)

Liu PY, Death AK \& Handelsman DJ 2003 Androgens and cardiovascular disease. Endocrine Reviews 24 313-340. (doi:10.1210/er.2003-0005)

Longo GM, Buda SJ, Fiotta N, Xiong W, Griener T, Shapiro S \& Baxter BT 2005 MMP-12 has a role in abdominal aortic aneurysms in mice. Surgery 137 457-462. (doi:10.1016/j.surg.2004.12.004)

Lopez MJ, Wong SK, Kishimoto I, Dubois S, Mach V, Friesen J, Garbers DL \& Beuve A 1995 Salt-resistant hypertension in mice lacking the guanylyl cyclase-A receptor for atrial natriuretic peptide. Nature 378 65-68. (doi:10.1038/378065a0)

MacTaggart JN, Xiong W, Knispel R \& Baxter BT 2007 Deletion of CCR2 but not CCR5 or CXCR3 inhibits aortic aneurysm formation. Surgery 142 284-288. (doi:10.1016/j.surg.2007.04.017)

Malhotra A, Buttrick P \& Scheuer J 1990 Effects of sex hormones on development of physiological and pathological cardiac hypertrophy in male and female rats. American Journal of Physiology 259 H866-H871.

Malkin CJ, Pugh PJ, Jones RD, Jones TH \& Channer KS 2003 Testosterone as a protective factor against atherosclerosis - immunomodulation and influence upon plaque development and stability. Journal of Endocrinology 178 373-380. (doi:10.1677/joe.0.1780373)

Malkin CJ, Jones RD, Jones TH \& Channer KS 2006a Effect of testosterone on ex vivo vascular reactivity in man. Clinical Science 111 265-274. (doi:10.1042/CS20050354)

Malkin CJ, Pugh PJ, West JN, van Beek EJ, Jones TH \& Channer KS $2006 b$ Testosterone therapy in men with moderate severity heart failure: a double-blind randomized placebo controlled trial. European Heart Journal 27 57-64.

Malkin CJ, Jones TH \& Channer KS 2009 Testosterone in chronic heart failure. Frontiers of Hormone Research 37 183-196. (doi:10.1159/000176053)

Malyusz M \& Ehrens HJ 1983 Effect of castration and testosterone substitution on the urinary output of gamma-glutamyl transpeptidase and of N-acetyl-beta-D-glucosaminidase of male rats with renovascular hypertension. Enzyme 29 93-99.

Malyusz M, Ehrens HJ \& Wrigge P 1985 Effect of castration on the experimental renal hypertension of the rat. Blood pressure, nephrosclerosis, long-chain fatty acids, and N-acetylation of PAH in the kidney. Nephron 40 96-99. (doi:10.1159/000183437)

Manzano-Fernandez S, Pastor-Perez FJ, Barquero-Perez O, Pascual-Figal DA, Goya-Esteban R, Rojo-Alvarez JL, Caamano-Fernandez A, Martinez Martinez-Espejo MD, Januzzi JL, Valdes M, et al. 2011 Short-term variability of heart rate turbulence in chronic heart failure. Journal of Cardiac Failure 17 735-741. (doi:10.1016/j.cardfail.2011.05.007)

Maron BJ, Casey SA, Hurrell DG \& Aeppli DM 2003 Relation of left ventricular thickness to age and gender in hypertrophic cardiomyopathy. American Journal of Cardiology 91 1195-1198. (doi:10.1016/S0002-9149(03)00266-2)

Marsh JD, Lehmann MH, Ritchie RH, Gwathmey JK, Green GE \& Schiebinger RJ 1998 Androgen receptors mediate hypertrophy in cardiac myocytes. Circulation 98 256-261. (doi:10.1161/01. CIR.98.3.256)

Martin-Merino E, Johansson S, Morris T \& Garcia Rodriguez LA 2011 Androgen deprivation therapy and the risk of coronary heart disease and heart failure in patients with prostate cancer: a nested case-control study in UK primary care. Drug Safety 34 1061-1077. (doi:10.2165/11594540-000000000-00000)

Published by Bioscientifica Ltd. 
Matsumoto A 1997 Hormonally induced neuronal plasticity in the adult motoneurons. Brain Research Bulletin 44 539-547. (doi:10.1016/ S0361-9230(97)00240-2)

Meusburger SM \& Keast JR 2001 Testosterone and nerve growth factor have distinct but interacting effects on structure and neurotransmitter expression of adult pelvic ganglion cells in vitro. Neuroscience 108 331-340. (doi:10.1016/S0306-4522(01)00420-1)

Meyer R, Linz KW, Surges R, Meinardus S, Vees J, Hoffmann A, Windholz O \& Grohe C 1998 Rapid modulation of L-type calcium current by acutely applied oestrogens in isolated cardiac myocytes from human, guinea-pig and rat. Experimental Physiology 83 305-321. (doi:10.1113/expphysiol.1998.sp004115)

Miyamoto H, Rahman M, Takatera H, Kang HY, Yeh S, Chang HC, Nishimura K, Fujimoto N \& Chang C 2002 A dominant-negative mutant of androgen receptor coregulator ARA54 inhibits androgen receptor-mediated prostate cancer growth. Journal of Biological Chemistry 277 4609-4617. (doi:10.1074/jbc.M108312200)

Miyamoto H, Yang Z, Chen YT, Ishiguro H, Uemura H, Kubota Y, Nagashima Y, Chang YJ, Hu YC, Tsai MY, et al. 2007 Promotion of bladder cancer development and progression by androgen receptor signals. Journal of the National Cancer Institute 99 558-568. (doi:10.1093/jnci/djk113)

Morales A 2010 Words of wisdom. Re: lower testosterone levels predict incident stroke and transient ischemic attack in older men. European Urology 58 182-183. (doi:10.1016/j.eururo.2010.04.017)

Morano I, Gerstner J, Ruegg JC, Ganten U, Ganten D \& Vosberg HP 1990 Regulation of myosin heavy chain expression in the hearts of hypertensive rats by testosterone. Circulation Research 66 1585-1590. (doi:10.1161/01.RES.66.6.1585)

Nettleship JE, Jones TH, Channer KS \& Jones RD 2007 Physiological testosterone replacement therapy attenuates fatty streak formation and improves high-density lipoprotein cholesterol in the Tfm mouse: an effect that is independent of the classic androgen receptor. Circulation 116 2427-2434. (doi:10.1161/ CIRCULATIONAHA.107.708768)

Neyses L \& T Pelzer 1995 The biological cascade leading to cardiac hypertrophy. European Heart Journal 16 (Supplement N) 8-11. (doi:10.1093/eurheartj/16.suppl_N.8)

Nguyen CT, Aaronson A, Morrissey RP, Agarwal M, Willix RD \& Schwarz ER 2011 Myths and truths of growth hormone and testosterone therapy in heart failure. Expert Review of Cardiovascular Therapy 9 711-720. (doi:10.1586/erc.11.25)

Normann S, de Veber G, Fobker M, Langer C, Kenet G, Bernard TJ, Fiedler B, Strater R, Goldenberg NA \& Nowak-Gottl U 2009 Role of endogenous testosterone concentration in pediatric stroke. Annals of Neurology 66 754-758. (doi:10.1002/ana.21840)

Obici S \& Rossetti L 2003 Minireview: nutrient sensing and the regulation of insulin action and energy balance. Endocrinology $1445172-5178$. (doi:10.1210/en.2003-0999)

Ouchi Y, Share L, Crofton JT, Iitake K \& Brooks DP 1987 Sex difference in the development of deoxycorticosterone-salt hypertension in the rat. Hypertension 9 172-177. (doi:10.1161/01.HYP.9.2.172)

Pan Y, Zhang H, Acharya AB, Patrick PH, Oliver D \& Morley JE 2005 Effect of testosterone on functional recovery in a castrate male rat stroke model. Brain Research 1043 195-204. (doi:10.1016/ j.brainres.2005.02.078)

Pastor-Perez FJ, Manzano-Fernandez S, Garrido Bravo IP, Nicolas F, Tornel PL, Lax A, de la Morena G, Valdes M \& Pascual-Figal DA 2011 Anabolic status and functional impairment in men with mild chronic heart failure. American Journal of Cardiology 108 862-866. (doi:10.1016/j.amjcard.2011.05.016)

Pearce WH \& Shively VP 2006 Abdominal aortic aneurysm as a complex multifactorial disease: interactions of polymorphisms of inflammatory genes, features of autoimmunity, and current status of MMPs. Annals of the New York Academy of Sciences 1085 117-132. (doi:10.1196/annals.1383.025)
PEPI Trial Writing Group 1995 Effects of estrogen or estrogen/progestin regimens on heart disease risk factors in postmenopausal women. The Postmenopausal Estrogen/Progestin Interventions (PEPI) Trial. The Writing Group for the PEPI Trial. JAMA 273 199-208. (doi:10.1001/jama.1995.03520270033028)

Pugh PJ, Jones TH \& Channer KS 2003 Acute haemodynamic effects of testosterone in men with chronic heart failure. European Heart Journal 24 909-915. (doi:10.1016/S0195-668X(03)00083-6)

Pugh PJ, Jones RD, West JN, Jones TH \& Channer KS 2004 Testosterone treatment for men with chronic heart failure. Heart 90 446-447. (doi:10.1136/hrt.2003.014639)

Qiu Y, Yanase T, Hu H, Tanaka T, Nishi Y, Liu M, Sueishi K, Sawamura T \& Nawata H 2010 Dihydrotestosterone suppresses foam cell formation and attenuates atherosclerosis development. Endocrinology $\mathbf{1 5 1}$ 3307-3316. (doi:10.1210/en.2009-1268)

Rautaharju PM, Zhou SH, Wong S, Calhoun HP, Berenson GS, Prineas R \& Davignon A 1992 Sex differences in the evolution of the electrocardiographic QT interval with age. Canadian Journal of Cardiology 8 690-695.

Razzak M 2012 Prostate cancer: cardiovascular risk and androgen deprivation therapy. Nature Reviews Urology 961.

Reckelhoff JF 2001 Gender differences in the regulation of blood pressure. Hypertension 37 1199-1208. (doi:10.1161/01.HYP.37.5.1199)

Reckelhoff JF, Zhang H, Srivastava K \& Granger JP 1999 Gender differences in hypertension in spontaneously hypertensive rats: role of androgens and androgen receptor. Hypertension 34 920-923. (doi:10.1161/01.HYP.34.4.920)

Reckelhoff JF, Yanes LL, Iliescu R, Fortepiani LA \& Granger JP 2005 Testosterone supplementation in aging men and women: possible impact on cardiovascular-renal disease. American Journal of Physiology: Renal Physiology 289 F941-F948. (doi:10.1152/ajprenal.00034.2005)

Regitz-Zagrosek V, Oertelt-Prigione S, Seeland U \& Hetzer R 2010 Sex and gender differences in myocardial hypertrophy and heart failure. Circulation Journal 74 1265-1273. (doi:10.1253/circj.CJ-10-0196)

Rosano GM, Leonardo F, Pagnotta P, Pelliccia F, Panina G, Cerquetani E, della Monica PL, Bonfigli B, Volpe M \& Chierchia SL 1999 Acute antiischemic effect of testosterone in men with coronary artery disease. Circulation 99 1666-1670. (doi:10.1161/01.CIR.99.13.1666)

Rossouw JE, Anderson GL, Prentice RL, LaCroix AZ, Kooperberg C, Stefanick ML, Jackson RD, Beresford SA, Howard BV, Johnson KC, et al. 2002 Risks and benefits of estrogen plus progestin in healthy postmenopausal women: principal results from the Women's Health Initiative randomized controlled trial. JAMA 288 321-333.

Rowell KO, Hall J, Pugh PJ, Jones TH, Channer KS \& Jones RD 2009 Testosterone acts as an efficacious vasodilator in isolated human pulmonary arteries and veins: evidence for a biphasic effect at physiological and supra-physiological concentrations. Journal of Endocrinological Investigation 32 718-723. (doi:10.1007/BF03346526)

Rowland NE \& Fregly MJ 1992 Role of gonadal hormones in hypertension in the Dahl salt-sensitive rat. Clinical and Experimental Hypertension. Part A 14 367-375. (doi:10.3109/10641969209036195)

Sadoshima J \& Izumo S 1993 Molecular characterization of angiotensin II - induced hypertrophy of cardiac myocytes and hyperplasia of cardiac fibroblasts. Critical role of the AT1 receptor subtype. Circulation Research 73 413-423. (doi:10.1161/01.RES.73.3.413)

Sakalihasan N, Delvenne P, Nusgens BV, Limet R \& Lapiere CM 1996 Activated forms of MMP2 and MMP9 in abdominal aortic aneurysms. Journal of Vascular Surgery 24 127-133. (doi:10.1016/S07415214(96)70153-2)

Schulze J, Julius U, Hanefeld M, Haller H \& Leonhardt W 1981 [Therapy of hypertriglyceridemia from a pathophysiological viewpoint]. Zeitschrift fur die Gesamte Innere Medizin 36 304-305.

Schwartz MW \& Porte D Jr 2005 Diabetes, obesity, and the brain. Science 307 375-379. (doi:10.1126/science.1104344)

Shahani S, Braga-Basaria M \& Basaria S 2008 Androgen deprivation therapy in prostate cancer and metabolic risk for atherosclerosis.

Published by Bioscientifica Ltd. 
Journal of Clinical Endocrinology \& Metabolism 93 2042-2049. (doi:10.1210/jc.2007-2595)

Simon JA 2001 Safety of estrogen/androgen regimens. Journal of Reproductive Medicine 46 (3 Supplement) 281-290.

Sinning C, Wild PS, Echevarria FM, Wilde S, Schnabel R, Lubos E, Herkenhoff S, Bickel C, Klimpe S, Gori T, et al. 2011 Sex differences in early carotid atherosclerosis (from the community-based Gutenberg-Heart Study). American Journal of Cardiology $\mathbf{1 0 7}$ 1841-1847. (doi:10.1016/j.amjcard.2011.02.318)

Smith MR 2008 Androgen deprivation therapy and risk for diabetes and cardiovascular disease in prostate cancer survivors. Current Urology Reports 9 197-202. (doi:10.1007/s11934-008-0035-y)

Somjen D, Kohen F, Jaffe A, Amir-Zaltsman Y, Knoll E \& Stern N 1998 Effects of gonadal steroids and their antagonists on DNA synthesis in human vascular cells. Hypertension 32 39-45. (doi:10.1161/ 01.HYP.32.1.39)

Stramba-Badiale M, Spagnolo D, Bosi G \& Schwartz PJ 1995 Are gender differences in QTc present at birth? MISNES Investigators. Multicenter Italian study on neonatal electrocardiography and sudden infant death syndrome. American Journal of Cardiology 75 1277-1278. (doi:10.1016/S0002-9149(99)80781-4)

Sugita S, Kawashima H, Tanaka T, Kurisu T, Sugimura K \& Nakatani T 2004 Effect of type I growth factor receptor tyrosine kinase inhibitors on phosphorylation and transactivation activity of the androgen receptor in prostate cancer cells: ligand-independent activation of the N-terminal domain of the androgen receptor. Oncology Reports 11 1273-1279.

Svartberg J, von Muhlen D, Schirmer H, Barrett-Connor E, Sundfjord J \& Jorde R 2004 Association of endogenous testosterone with blood pressure and left ventricular mass in men. The Tromso Study. European Journal of Endocrinology 150 65-71. (doi:10.1530/ eje.0.1500065)

Svartberg J, von Muhlen D, Mathiesen E, Joakimsen O, Bonaa KH \& Stensland-Bugge E 2006 Low testosterone levels are associated with carotid atherosclerosis in men. Journal of Internal Medicine 259 576-582. (doi:10.1111/j.1365-2796.2006.01637.x)

Taggart H, Sheridan B \& Stout RW 1980 Sex hormone levels in younger male stroke survivors. Atherosclerosis 35 123-125. (doi:10.1016/ 0021-9150(80)90034-9)

Tangredi JF \& Buxton IL 2001 Hypertension as a complication of topical testosterone therapy. Annals of Pharmacotherapy 35 1205-1207. (doi:10.1345/aph.1A020)

Thompson RW \& Baxter BT 1999 MMP inhibition in abdominal aortic aneurysms. Rationale for a prospective randomized clinical trial. Annals of the New York Academy of Sciences 878 159-178. (doi:10.1111/j.1749-6632.1999.tb07682.x)

Tirassa P, Thiblin I, Agren G, Vigneti E, Aloe L \& Stenfors C 1997 Highdose anabolic androgenic steroids modulate concentrations of nerve growth factor and expression of its low affinity receptor (p75-NGFr) in male rat brain. Journal of Neuroscience Research 47 198-207.

Toh S, Hernandez-Diaz S, Logan R, Rossouw JE \& Hernan MA 2010 Coronary heart disease in postmenopausal recipients of estrogen plus progestin therapy: does the increased risk ever disappear? A randomized trial. Annals of Internal Medicine 152 211-217. (doi:10.7326/0003-4819-152-4-201002160-00005)

Towbin JA \& Lipshultz SE 1999 Genetics of neonatal cardiomyopathy. Current Opinion in Cardiology 14 250-262. (doi:10.1097/00001573199905000-00010)

Tsai HK, D’Amico AV, Sadetsky N, Chen MH \& Carroll PR 2007 Androgen deprivation therapy for localized prostate cancer and the risk of cardiovascular mortality. Journal of the National Cancer Institute 99 1516-1524.

Turhan S, Tulunay C, Gulec S, Ozdol C, Kilickap M, Altin T, Gerede M \& Erol C 2007 The association between androgen levels and premature coronary artery disease in men. Coronary Artery Disease 18 159-162. (doi:10.1097/MCA.0b013e328012a928)
Uchida M, Palmateer JM, Herson PS, DeVries AC, Cheng J \& Hurn PD 2009 Dose-dependent effects of androgens on outcome after focal cerebral ischemia in adult male mice. Journal of Cerebral Blood Flow \& Metabolism 29 1454-1462. (doi:10.1038/jcbfm.2009.60)

Vicencio JM, Ibarra C, Estrada M, Chiong M, Soto D, Parra V, Diaz-Araya G, Jaimovich E \& Lavandero S 2006 Testosterone induces an intracellular calcium increase by a nongenomic mechanism in cultured rat cardiac myocytes. Endocrinology 147 1386-1395. (doi:10.1210/en.2005-1139)

Vigna GB \& Bergami E 2005 Testosterone replacement, cardiovascular system and risk factors in the aging male. Journal of Endocrinological Investigation 28 (11 Supplement Proceedings) 69-74.

Walker WH 2003 Nongenomic actions of androgen in Sertoli cells. Current Topics in Developmental Biology 56 25-53. (doi:10.1016/ S0070-2153(03)01006-8)

Wang X, Yeh S, Wu G, Hsu CL, Wang L, Chiang T, Yang Y, Guo Y \& Chang C 2001 Identification and characterization of a novel androgen receptor coregulator ARA267-alpha in prostate cancer cells. Journal of Biological Chemistry 276 40417-40423. (doi:10.1074/ jbc.M104765200)

Wang M, Baker L, Tsai BM, Meldrum KK \& Meldrum DR 2005a Sex differences in the myocardial inflammatory response to ischemia-reperfusion injury. American Journal of Physiology: Endocrinology and Metabolism 288 E321-E326. (doi:10.1152/ ajpendo.00278.2004)

Wang M, Tsai BM, Kher A, Baker LB, Wairiuko GM \& Meldrum DR $2005 b$ Role of endogenous testosterone in myocardial proinflammatory and proapoptotic signaling after acute ischemia-reperfusion. American Journal of Physiology: Heart and Circulatory Physiology 288 H221-H226.

Wang M, Crisostomo PR, Markel TA, Wang Y \& Meldrum DR 2008 Mechanisms of sex differences in TNFR2-mediated cardioprotection. Circulation 118 (14 Supplement) S38-S45.

Wang RS, Yeh S, Tzeng CR \& Chang C 2009 Androgen receptor roles in spermatogenesis and fertility: lessons from testicular cell-specific androgen receptor knockout mice. Endocrine Reviews 30 119-132. (doi:10.1210/er.2008-0025)

Webb CM, Adamson DL, de Zeigler D \& Collins P 1999a Effect of acute testosterone on myocardial ischemia in men with coronary artery disease. American Journal of Cardiology 83 437-439, A439. (doi:10.1016/S0002-9149(98)00880-7)

Webb CM, McNeill JG, Hayward CS, de Zeigler D \& Collins P 1999 b Effects of testosterone on coronary vasomotor regulation in men with coronary heart disease. Circulation 100 1690-1696. (doi:10.1161/01. CIR.100.16.1690)

Weber KT \& Brilla CG 1991 Pathological hypertrophy and cardiac interstitium. Fibrosis and renin-angiotensin-aldosterone system. Circulation 83 1849-1865. (doi:10.1161/01.CIR.83.6.1849)

Weinberg EO, Thienelt CD, Katz SE, Bartunek J, Tajima M, Rohrbach S, Douglas PS \& Lorell BH 1999 Gender differences in molecular remodeling in pressure overload hypertrophy. Journal of the American College of Cardiology 34 264-273. (doi:10.1016/ S0735-1097(99)00165-5)

Weintraub NL 2009 Understanding abdominal aortic aneurysm. New England Journal of Medicine 361 1114-1116. (doi:10.1056/ NEJMcibr0905244)

Wexler RK, Elton T, Pleister A \& Feldman D 2009 Cardiomyopathy: an overview. American Family Physician 79 778-784.

Wiinberg N, Hoegholm A, Christensen HR, Bang LE, Mikkelsen KL, Nielsen PE, Svendsen TL, Kampmann JP, Madsen NH \& Bentzon MW 1995 24-h ambulatory blood pressure in 352 normal Danish subjects, related to age and gender. American Journal of Hypertension 8 978-986. (doi:10.1016/0895-7061(95)00216-2)

Wolf DA, Burke AP, Patterson KV \& Virmani R 2002 Sudden death following rupture of a right ventricular aneurysm 9 months after ablation therapy of the right ventricular outflow tract. Pacing and Clinical Electrophysiology 25 1135-1137. (doi:10.1046/j.1460-9592.2002.01135.x) 
Woods LL, Morgan TK \& Resko JA 2010 Castration fails to prevent prenatally programmed hypertension in male rats. American Journal of Physiology. Regulatory, Integrative and Comparative Physiology 298 R1111-R1116. (doi:10.1152/ajpregu.00803.2009)

Wu FC \& von Eckardstein A 2003 Androgens and coronary artery disease. Endocrine Reviews 24 183-217. (doi:10.1210/er.2001-0025)

Xin HB, Senbonmatsu T, Cheng DS, Wang YX, Copello JA, Ji GJ, Collier ML, Deng KY, Jeyakumar LH, Magnuson MA, et al. 2002 Oestrogen protects FKBP12.6 null mice from cardiac hypertrophy. Nature 416 334-338. (doi:10.1038/416334a)

Xue B, Pamidimukkala J \& Hay M 2005 Sex differences in the development of angiotensin II-induced hypertension in conscious mice. American Journal of Physiology: Heart and Circulatory Physiology 288 H2177-H2184. (doi:10.1152/ajpheart.00969.2004)

Yamashita S, Lai KP, Chuang KL, Xu D, Miyamoto H, Tochigi T, Pang ST, Li L, Arai Y, Kung HJ, et al. 2012 ASC-J9 suppresses castration-resistant prostate cancer growth through degradation of full-length and splice variant androgen receptors. Neoplasia 14 74-83. (doi:10.1593/neo.111436)

Yang SH, Perez E, Cutright J, Liu R, He Z, Day AL \& Simpkins JW 2002 Testosterone increases neurotoxicity of glutamate in vitro and ischemia-reperfusion injury in an animal model. Journal of Applied Physiology 92 195-201. (doi:10.1063/1.1486251)

Yang T, Huang YG, Ye W, Hansen P, Schnermann JB \& Briggs JP 2005 Influence of genetic background and gender on hypertension and renal failure in COX-2-deficient mice. American Journal of Physiology: Renal Physiology 288 F1125-F1132. (doi:10.1152/ajprenal.00219.2004)

Yang Z, Chang YJ, Yu IC, Yeh S, Wu CC, Miyamoto H, Merry DE, Sobue G, Chen LM, Chang SS, et al. 2007 ASC-J9 ameliorates spinal and bulbar muscular atrophy phenotype via degradation of androgen receptor. Nature Medicine 13 348-353. (doi:10.1038/nm1547)

Yeap BB, Hyde Z, Almeida OP, Norman PE, Chubb SA, Jamrozik K, Flicker L \& Hankey GJ 2009 Lower testosterone levels predict incident stroke and transient ischemic attack in older men. Journal of Clinical Endocrinology \& Metabolism 94 2353-2359. (doi:10.1210/jc.2008-2416)

Yeh S, Tsai MY, Xu Q, Mu XM, Lardy H, Huang KE, Lin H, Yeh SD, Altuwaijri S, Zhou X, et al. 2002 Generation \& characterization of androgen receptor knockout (ARKO) mice: an in vivo model for the study of androgen functions in selective tissues. PNAS 99 13498-13503. (doi:10.1073/pnas.212474399)

Yoshimura K, Aoki H, Ikeda Y, Fujii K, Akiyama N, Furutani A, Hoshii Y, Tanaka N, Ricci R, Ishihara T, et al. 2005 Regression of abdominal aortic aneurysm by inhibition of c-Jun N-terminal kinase. Nature Medicine 11 1330-1338. (doi:10.1038/nm1335)

Yu IC, Lin HY, Liu NC, Wang RS, Sparks JD, Yeh S \& Chang C 2008 Hyperleptinemia without obesity in male mice lacking androgen receptor in adipose tissue. Endocrinology 149 2361-2368. (doi:10.1210/en.2007-0516)

Yu S, Zhang C, Lin CC, Niu Y, Lai KP, Chang HC, Yeh SD, Chang C \& Yeh S 2011 Altered prostate epithelial development and IGF-1 signal in mice lacking the androgen receptor in stromal smooth muscle cells. Prostate 71 517-524.

Yu IC, Lin HY, Liu NC, Sparks JD, Yeh S, Fang LY, Chen L \& Chang C 2013 Neuronal androgen receptor regulates insulin sensitivity via suppression of hypothalamic NF-kappaB-mediated PTP1B expression. Diabetes 62 411-423. (doi:10.2337/db12-0135)

Zhang Y, Naggar JC, Welzig CM, Beasley D, Moulton KS, Park HJ \& Galper JB 2009 Simvastatin inhibits angiotensin II-induced abdominal aortic aneurysm formation in apolipoprotein E-knockout mice: possible role of ERK. Arteriosclerosis, Thrombosis, and Vascular Biology 29 1764-1771. (doi:10.1161/ATVBAHA.109.192609)

Zimmerman FH 2012 Cardiovascular disease and risk factors in law enforcement personnel: a comprehensive review. Cardiology in Review 20 159-166. (doi:10.1097/CRD.0b013e318248d631)

Received in final form 4 December 2015

Accepted 13 January 2016

Accepted Preprint published online 14 January 2016
(C) 2016 Society for Endocrinology Printed in Great Britain 